\title{
Inhibition Activity of Lung Cancer Cells A549 by Trigona Propolis From Indonesia
}

\author{
$1^{\text {st }}$ Achmad Tjachja Nugraha ${ }^{1}, 2^{\text {nd }}$ La Ode Sumarlin ${ }^{2}$ \\ \{sumarlin@uinjkt.ac.id ${ }^{1}$ \} \\ UIN Syarif Hidayatullah, Faculty of Science and Technology, Jakartaㄹ, UIN Syarif Hidayatullah, \\ Chemistry Faculty of Science and Technology Faculty, Jakarta ${ }^{2}$
}

\begin{abstract}
The results showed that propolis trigona has high content of flavonoids, vitamin $C$ and $\beta$-carotene compounds. Therefore, the whole exploration effort of propolis properties becomes an important study and research especially anticancer activity of lung cancer. Trigona propolis samples which is used are from Indonesian beekeepers. Lung anticancer activity was measured by MTT method (3- (4,5-Dimethylthiazol-2-yl) -2,5diphenyltetrazolium bromide) on A549 cell. The results showed the inhibition of A549 lung cancer cell by trigona propolis is higher with increasing concentration ( 0.625 to 100 $\mathrm{ppm}$ ). The results of phytochemical analysis showed that the trigona propolis samples contained alkaloids, flavonoids, quinones and tannins. In addition, trigona propolis has the ability to inhibit A549 cells of $78.21 \pm 0.02 \%$ at $100 \mathrm{ppm}$ concentration. This inhibitory ability is higher in line with the increase in sample concentration. Therefore, Indonesian trigona propolis has potential as a lung anticancer.
\end{abstract}

Keywords: component; Cell A549, Lung cancer, trigona propolis

\section{Introduction}

Cancer is one of the leading causes of death in humans. By 2015, cancer ranks second ( 8.8 million or $22 \%$ ) of the leading cause of death from non-contagious diseases in the global population [1]. In the last decade lung cancer is the most common cause of death around the world [2]. In 2012, it was estimated that 1,8 million new cases arose and reached $12,9 \%$ from whole cancer diagnostics [3]. In Indonesia during the year 2010-2013, lung cancer is one of the three most common cancer in Dharmais Cancer Hospital and the number of new cases and deaths from cancer continues to increase [4]. Other data also shown that the survival rate of lung cancer patients in Indonesia is only $12 \%$ [5].

Therefore therapeutic efforts for lung cancer need to be raised and get high attention from all parties. Therapeutic efforts can be done with the use of natural alternative materials such as propolis especially from trigona spp. The results of research on several samples of propolis prove the potential of anti-cancer and antiproliferation agents such as Turkish propolis in A549 lung cancel cells [6], propolis from Thailand against A549 cells and HeLa cells [7], propolis against AGS cells for gastric cancer [8], propolis from Poland against A549 and H23 cells [9]. Propolis has properties as anticancer, antiviral, antifungal and antibiotic [10].

Mahani et al. [11] states that the important active compound in pharmacology and biological activity of propolis are flavonoids, phenolic and aromatic compounds. The flavonoid compounds identified in Polish propolis include flavones, flavonones, flavonolol, 
flavonols and phenolic acids. Multi-interaction of various complex chemical compounds in propolis is an important biological activity which related with its anticancer effects [12].

In Indonesia the anticancer ability of propolis on lung cancer using A549 cells has not been studied by many researchers, especially propolis produced from local Indonesia. It is expected that this research will enrich information about the inhibition capability of trigona propolis against A549 cells so it can be used as an alternative therapy of lung cancer.

\section{Research Methods}

\subsection{Tools and Materials}

Cells used are Cell Vero (ATCC CCL 81) obtained from IPB Primate Research Center (PSSP), DMSO, Cell Growing Media: Dulbecco's Modified Eagle's Medium (D-MEM), RPMI 1640, Fetal Bovine Serum (FBS) 10\%, Penicillin 100U/mL and Streptomycin 100 $\mathrm{ug} / \mathrm{mL}$. Propolis samples derived from Indonesian commercial propolis which have been added with propylene glycol collected from local farmers in Indonesia.

\subsection{Preparation of Propolis Extract}

$1 \mathrm{mg}$ of the propolis fraction was weighed, then dissolved with $1000 \mu \mathrm{l}$ of DMSO $99.5 \%$ and centrifuged until homogeneous. This is used as standard solution of the propolis fraction with a concentration of $1000 \mathrm{ppm}$. The base solution was diluted for a series of test solutions with concentrations of $50 \mathrm{ppm}, 100 \mathrm{ppm}, 200 \mathrm{ppm}, 400 \mathrm{ppm}$ and $800 \mathrm{ppm}$.

\subsection{Quantitation of Total Phenolic Compound}

The propolis sample was weighed as much as $100 \mathrm{mg}$ and dissolved in $10 \mathrm{ml}$ of distilled water. Subsequently $0,5 \mathrm{ml}$ of mixture was taken and added with $0.3 \mathrm{ml}$ of Folin-Ciocalteu, 2 $\mathrm{ml}$ of $15 \% \mathrm{Na}_{2} \mathrm{CO}_{3}$ and $2.2 \mathrm{ml}$ of distilled water. The solution homogenized and incubated for 2 hours then the uptake measured using Perkin Elmer Lambda UV-VIS Spectrophotometer at wavelength of $750 \mathrm{~nm}$. Measurements are repeated 3 times. The total phenolic content is expressed as the equivalent amount of $\mathrm{mg}$ of the gallic acid (GAE) per $1 \mathrm{~g}$ sample.

\subsection{Quantitation of Total Flavonoid Compound}

Propolis samples were taken each of $100 \mathrm{mg}$ dissolved in $10 \mathrm{ml}$ of methanol in the test tube. Next the mixture was filtered, taken as much as $5 \mathrm{ml}$ and added $5 \mathrm{ml} \mathrm{AlCl}_{3} \%$ (b/v) reagent. The solution homogenized and incubated for 10 minutes then the uptake measured using Perkin Elmer Lambda UV-VIS Spectrophotometer at wavelength of $415 \mathrm{~nm}$ [13]. Measurements are repeated 3 times. The flavonoid content is considered as the equivalent amount of $\mathrm{mg}$ of quercetin (QE) per $1 \mathrm{~g}$ sample.

\subsection{Quantitation of Vitamin C compound}

A total of $100 \mathrm{mg}$ of propolis sample was added with $10 \mathrm{ml}$ of $1 \%$ metaphosphoric acid then incubated at room temperature for $45 \mathrm{~min}$. The solution is then filtered using Whatman No. 41 and $1 \mathrm{~mL}$ of filtrate was taken then added with $9 \mathrm{~mL}$ DCIP. The mixture was homogenized and incubated for $30 \mathrm{~min}$ at room temperature and then the uptake measured using Perkin Elmer Lambda UV-VIS Spectrophotometer at wavelength of $519 \mathrm{~nm}$. Measurements are repeated 3 times. The vitamin $\mathrm{C}$ content is expressed as the equivalent amount of mg ascorbic acid (AA) per $1 \mathrm{~g}$ sample. 


\subsection{A549 Monolayer Cell Preparation}

A549 cells that have grown should be subcultured. The cell media was discarded and PBS was added as much as $10 \mathrm{~mL}$ to clean the flask from the rest of the media, then PBS was discarded. $5 \mathrm{~mL}$ Trypsin $(0.125 \%)$ was added to the flask, incubated at $37^{\circ} \mathrm{C}$ for 5 mins. The cell that had been released from the substrate was inserted into a $15 \mathrm{~mL}$ tube and centrifuged $500 \mathrm{~g}$ for 5 minutes. The supernatant was discarded. The calculation of cells using haemocytometer was then prepared in accordance with the importance for the test. Cells were incubated in $\mathrm{CO}_{2}$ incubator with concentration of $5 \%$.

\subsection{Cell Calculation}

A total of $50 \mu \mathrm{l}$ cell solutions was added with $50 \mu \mathrm{l}$ trypan blue and passed into the haemocytometer, then observed and the living cells counted (not absorbing the color) of 2 large squares. The results obtained are calculated using the formula:

$$
\text { Cell per } m \bar{l}=\text { mean of cell calculated } x \text { dilution factor } x 10^{4}
$$

\subsection{MTT Assay}

The grown cell on the T25 flask is subcultured and is moved on 96 wells tissue culture plate with the amount of 5000 cells / well and incubated for 24 hours in growth medium at 37 ${ }^{\circ} \mathrm{C}$ and $5 \% \mathrm{CO}_{2}$. The trigona propolis sample fraction of each concentration was added as much as $100 \mu \mathrm{L}$ / well, the cells without treatment were included as the cell control was subsequently incubated for 48 hours. Compound 3- (4,5-Dimethylthiazol-2-yl) -2,5diphenyltetrazolium bromide (MTT) was added and incubated for 4 hours at $37^{\circ} \mathrm{C}$ and $5 \%$ $\mathrm{CO}_{2}$. Cell supernatant removed, formazan crystals formed dissolved with $70 \%$ ethanol. Optical density readings (OD) are performed using microplate reader at $565 \mathrm{~nm}$ wavelength.

Calculation of \% inhibition:

$\%$ inhibition $=\underline{\text { OD cell control }- \text { OD treatment in cell } \times 100 \%}$ OD cell control

\subsection{Data Analysis}

The relationship between the concentration of the test preparation and the absorbance data were analyzed statistically using one-way variance analysis (ANOVA) followed by Duncan's Multiple Range Test.

\section{Result and Discussion}

\subsection{Phytochemical Compund}

The results showed that the propolis samples contained alkaloids, flavonoids, quinones and tannins (Table 1). This result is in line with Halim et al., [14] research which conducted a study comparing Indonesian Propolis (PI) and Brazilian Propolis (PB) and showed the presence of flavonoids, tannins, steroids, triterpenoids, saponins, alkaloids and glycosides.

Table 1. Results of Phytochemical Screening of Trigona Sp. Propolis

Phytochemical test Result




\begin{tabular}{lc}
\hline Alkaloids & + \\
Flavonoids & + \\
Triterpenoids and steroids & - \\
Quinones & + \\
Tannins & + \\
Saponins & - \\
\hline
\end{tabular}

Table 2. Quantitative Test Results of Trigona Sp. Propolis Active Compound

\begin{tabular}{cc}
\hline $\begin{array}{c}\text { Active } \\
\text { Compound }\end{array}$ & Quantitative \\
\hline Total Flavonoid & $2.02 \pm 1.13 \mathrm{mg}$ quersetin \\
& ekuivalen/gram propolis \\
Total Phenolic & $1.98 \pm 0.06 \mathrm{mg} \mathrm{GAE} /$ gram \\
& propolis \\
Vitamin C & $22.07 \pm 3.25 \mathrm{mg} /$ gram propolis \\
\hline
\end{tabular}

The results of the analysis of total phenolics and flavonoids showed that the propolis samples contained each $1.98 \pm 0.06 \mathrm{mg}$ GAE / gram propolis; $2.02 \pm 1.13 \mathrm{mg}$ equivalent quercetin / gram propolis (Table 2). The content of phenolic compounds and vitamin $\mathrm{C}$ is related to its ability as bioactive. Ananda et al., [15] has conducted a study of propolis from Phayao Thailand Province found its flavonoid content is $20.49 \pm 0.62 \mathrm{mg}$ quercetin / g extract. In addition, there was also an inhibition of cell proliferation of A549 line and HeLa cell by propolis extract. Chang et al., [16] found that the total flavonoids of six samples of propolis from Taiwan, Brazil and China ranged from $10.38 \pm 0.14 \%$ to $24.91 \pm 0.53 \%$. Other researchers have found that the total flavonoid content varies in propolis from Indonesia [17]. Huang et al., [18] discovered that flavonoid compounds with flavonoids, phenylpropanoids, terpene, stilbenes, lignans, coumarins was respectively found from 200 reported samples.

\subsection{Anticancer Test (A549 lung cancer cell)}

A cytotoxic test was performed on A549 lung cancer cells to investigate potential inhibition and toxic effects on cell growth due to the treatment of propolis extract at various concentrations. The test was performed to determine the levels of test samples that could have a toxic effect on the growth of lung cancer cells A549 to $50 \%$ of the cell population (IC50). The test results showed that the higher the concentration is $(0.625-100 \mathrm{ppm})$ (Table 3$)$ the more inhibitory ability increase. In this study the highest inhibitory activity at $100 \mathrm{ppm}$ concentration was $78.21 \pm 0.02 \%$ (Table 3 ).

Table 3. Test Results of A549 Cell Inhibition Activity

\begin{tabular}{ll}
\hline Concentration of propolis & Inhibition activity (\%) \\
\cline { 1 - 1 }$(\mathbf{p p m})$ & \\
\hline 100 & $78,21 \pm 0,02$ \\
50 & $49,64 \pm 0,02$ \\
25 & $43,44 \pm 0,01$ \\
10 & $33,97 \pm 0,02$ \\
5 & $29,08 \pm 0,02$ \\
\hline
\end{tabular}




\begin{tabular}{ll}
\hline 2,5 & $17,86 \pm 0,01$ \\
1,25 & $4,59 \pm 0,03$ \\
0,625 & $-4,66 \pm 0,03$ \\
Cell control & 0 \\
\hline
\end{tabular}

The form of Propolis Trigona laeviceps, which is a stringless bee, can inhibit proliferation of colon cancer, breast, liver and lung cancers cell lines [19]. This shows that the propolis extract has the ability to inhibit A549 lung cancer cells and potential as a chemotherapy agent. This is in accordance with research conducted on ethanol extract of propolis by Kouidhi et al., [20] against Tunisian EEP propolis from Tunisia showed antiproliferative activity against HT29, A549, Hep-2, RAW 264.7 cells and Vero cancer cells. Ananda et al., [15] also showed that the treatment of propolis extract on A549 cells affected cell histology. Ananda et al., [15] also tested the cytotoxicity of propolis on cell A549 using the MTT test. The results presented that A549 cells could be inhibited after 24,48 and 72 hours of treatment with propolis extracts from two extraction methods at various doses given.

Presumably the inhibition mechanism as antiproliferative activity of cell is due to the presence of flavonoids may be associated with propolis in cancer cells. In this study the inhibition of A549 cells is thought to be due to the presence of flavonoids that are also measurable on the trigona propolis samples. Propolis consists of flavonoid groups including tectochrysin, galangin, pinocembrin and pinocembrin-7-methyleter, and these substances can inhibit the proliferation of HeLa cells over other substances [21]. In addition, the inhibition of cancer cell growth depends on the origin of geography and the source of propolis which affect the composition of the propolis [22].

The mechanism of action of flavonoids against A549 cancer cells has been investigated by Banerjee et al., [23] (2002) through the reaction of Prostaglandin E2 (PGE2). The result of study in Brazilian green propolis, Herrera et al., [24] uncovered an apoptosis mechanism of caspase-independent 549 cell through p53 mitochondrial independent pathways and cell cycle capture by p 21 regulatory enhancement. It is the potential mechanism that sample of propolis from Indonesia can prevent or treat lung cancer. Li et al., [25] also emphasized the influence of flavon isohamnetin compounds in inhibiting the activity of cell proliferation A549.

\section{Conclusion}

The results of this study can be concluded that:

1. Phytochemically the trigona propolis sample contains alkaloids, flavonoids, quinones and tannins.

2. Trigona propolis has the ability to inhibit cell A549 of $78.21 \pm 0.02 \%$.

3. The higher the concentration of propolis samples, the inhibitory ability of A549 cells is also higher.

4. Trigona propolis used in research originating from Indonesia has the potential as a lung anticancer

Acknowledgements. This paper in conjuction with the 1st International Conference on Islam, Science and Technology (ICONIST), Malang East Java. 


\section{References}

[1] WHO, 2017. NCD Mortality and Morbidity. Global Health Observatory (GHO). Available at: http://www.who.int/gho/ncd/mortality_morbidity/en/ [Accessed September 5, 2017].

[2] Ferlay J, Soerjomataram I, Dikshit R, Eser S, Mathers C, Rebelo M, DM, Forman D, Bray F. GLOBOCAN 2012v1.0, 2013. Cancer Incidence and Mortality Worldwide. IARC Cancer Base No. 11. Lyon, France: International Agency for Research on Cancer

[3] Vos, T, Allen C, Arora M, Barber, Ryan M, Bhutta ZA, Brown A, Carter A, Casey DC, Charlson FJ, Chen AZ, Coggeshall M, and Cornaby L. 2016. Global, regional, and national incidence, prevalence, and years lived with disability for 310 diseases and injuries, 19902015: a systematic analysis for the Global Burden of Disease Study 2015. The Lancet 1545(388), 10053

[4] InfoDATIN 2015. Pusat Data Dan Informasi Kementerian Kesehatan RI

[5] Global Facts and Figures 3rd Edition. 2015. American Cancer Society: Atlanta

[6] S. Demir, Y. Aliyazicioglu, I. Turan, S. Misir, A. Mentese, S.O. Yaman, K. Akbulut, K.

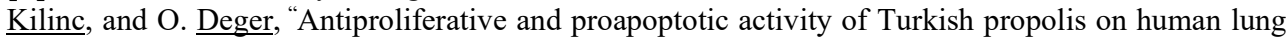
cancer cell line," Nutr. Cancer, vol. 68, pp.165-72. December 2015

[7] S.K. Ananda, T. Khajornsak, C. Panuwan, and T. Yingmanee, "Propolis extracts from the northern region of Thailand suppress cancer cell growth through induction of apoptosis pathways," Invest. New Drugs, vol. 34, pp.707-722, September 2016.

[8] N.A. Sarteshnizi, M.M. Dehkordi, S.K. Farsani, and H. Teimor, "Anticancer activity of ethanolic extract of propolis on AGS cell line," J. Herb.Med. Pharmacol, vol. 4, pp.29-34, November 2014.

[9] M. Popova, G. Efstathia, S.W. Krystyna, G. Konstantia, W. Jaroslaw, B. Vassya, K. Haralabos, S. Gregory, G.B. Katarzyna, A. Beata, and C. Ioanna, "Characterization and Biological Evaluation of Propolis from Poland," Molecules, vol. 22, pp.1-13, July 2017.

[10] B. Haryanto, Z. Hasan, Kuswandi, \& I.M. Artika, "Penggunaan Propolis untuk Meningkatkan Produktivitas Ternak Sapi Peranakan Ongole (PO),” JITV, vol. 17, pp.201-206, September 2012.

[11] Mahani, RA. Karim, \& N. Nurjanah, "Keajaiban Propolis Trigona," Jakarta: Pustaka Bunda, 2011

[12] R. Kubina, D.A. Kabała, A. Dziedzic, B. Bielec, R.D. Wojtyczka, R.J. Bułdak, M. Wyszyńska, P.B. Stawiarska, and S.E. Szaflarska, "The Ethanol Extract of Polish Propolis Exhibits AntiProliferative and/or Pro-Apoptotic Effect on HCT 116 Colon Cancer and Me45 Malignant Melanoma Cells In Vitro Conditions," Adv. Clin. Exp. Med, vol.24, pp.203-212, April 2015.

[13] A. Meda, C.E Lamien, M. Romito, J. Millogo, O.G. Nacoulma, "Determination of the total phenolic, flavonoid and proline contents in Burkina Fasan honey, as well as their radical scavenging activity," Food Chem, vol.91, pp.571-577, July 2005

[14] E. Halim, Hardinsyah, S. Noorwati, S. Ahmad, A. Made, and H. Yahdiana, "Kajian Bioaktif Dan Zat Gizi Propolis Indonesia Dan Brasil(Bioactive Compounds And Nutrients Content Of Indonesian And Brazilian Propolis)," Jurnal Gizi dan Pangan, vol.7, pp.1-6, Maret 2012.

[15] S.K. Ananda, T. Khajornsak, C. Panuwan, and T. Yingmanee, "Antioxidant and Anti-cancer Cell Proliferation Activity of Propolis Extracts from Two Extraction Methods," Asian Pac. J. Cancer Prev, vol.14, pp.6991-6995, November 2013.

[16] C.C. Chang, H.Y. Ming, M.W. Hwei, and C.C. Jiing, "Estimation of Total Flavonoid Content in Propolis by Two Complementary Colorimetric Methods," J. Food Drug Anal, vol.10, No. 3, pp.178182, May 2002.

[17] N. Pujirahayu, R. Halimahtussadiyah, and U. Zakiah, "Properties And Flavonoids Content In Propolis Of Some Extraction Method Of Raw Propolis," Int. J. Pharm. Pharm. Sci, vol 6, pp.338 340, May 2014.

[18] S. Huang, C.P. Zhang, K. Wang, G.Q. Li and F.L. Huang, "Review Recent Advances in the Chemical Composition of Propolis," Molecules, vol.19, pp.19610-19632, November 2016. 
[19] S. Umthong, P. Phuwapraisirisan, S. Puthong, and C. Chanchao, "In vitro antiproliferative activity of partially purified Trigona laeviceps propolis from Thailand on human cancer cell lines," BMC Complemen. Altern. Med, vol.11, pp.37-44, May 2011.

[20] B. Kouidhi, T. Zmantar, and A. Bakhrouf, "Anti-cariogenic and anti-biofilms activity of Tunisian propolis extract and its potential protective effect against cancer cells proliferation," Anaerobe, vol.16, pp.566-571, October 2010.

[21] M. Barbaric, K. Miskovic, M. Bojic, M.B. Lončar, B.A. Smolčić, Z. Debeljak, and S.M. Medić, "Chemical composition of the ethanolic propolis extracts and its effect on HeLa cells," $J$ Ethnopharmacol. vol.135, pp.772-778. April 2011.

[22] Syamsudin, S. Wiryowidagdo, P. Simanjuntak, and W.L. Heffen, "Chemical composition of propolis from different regions in Java and their cytotoxic activity," Am. J. Biochem \& Biotech, vol.5, pp.180-183, 2009.

[23] M. Banerjee, D. Worth, D.M. Prowse, andM. Nikolic, "Pak1 Phosphorylation on $\mathrm{t} 212$ affects microtubules in cells undergoing mitosis," Curr. Biol, vol.12, pp.1233-1239. July 2002.

[24] Herrera YF, Alexis DG, Jenny RF, Hermis RS and José MS, "Brazilian green propolis induced apoptosis in human lung cancer A549 cells through mitochondrial-mediated pathway," J Pharm. Pharmacol, vol.67, pp.1448-1456, July 2015.

[25] Q. Li, Q.R. Fu, L.Y. Chun, M.Z. Li, Y.L. Yan, X. Jing, Z. Ling, and G.W. Zhen, "Antiproliferation Effects of Isorhamnetin on Lung Cancer Cells in Vitro and in Vivo," Asian Pac J Cancer Prev, Vol 16, pp. 3035-3042, July 2015. 